ROCZNIKI KULTUROZNAWCZE

Tom/Vol. XII, numer/number 1 - 2021

DOI: http://doi.org/10.18290/rkult21121-3

ERIC HIRSCH

\title{
AESTHETIC HISTORISM \\ AND THE AESTHETICS OF TIDIBE: \\ RITUAL, PERFORMANCE, AND CONTESTED PERCEPTIONS OF "SKIN" IN THE PAPUAN HIGHLANDS
}

\section{INTRODUCTION}

The aesthetic horizons of Western people are very large. Depending on the public concerned, we (writing as a Western person) have no problem appreciating the art of Giotto and Rembrandt or that of Michelangelo and Picasso or Duchamp and different forms of African art. A critic that disparaged the art of Cezanne or artworks from native peoples of Latin America because they did not follow the aesthetic principles recognised by classical Greek and Roman theory would not be considered a thoughtful critic; he or she would not be taken seriously (AUERBACH 1949, 110).

This state of affairs has not always been the case. It is the outcome of historical perspective or what came to be called historism (or more commonly historicism). Here I follow Auerbach's compelling analysis of this shift in aesthetic perception as much as historical understanding. Historism is the idea that every civilisation or society has its own aesthetic principles as well as forms of life and each need to be understood as creations of variable particular circumstances. These cannot be judged by any absolute rules or principles but only by their own individual development.

However, before the sixteenth century the historical or geographical perspectives of Europeans were not wide enough to entertain such ideas. Even in the Renaissance when there was an expansion of horizons through the encounter with a variety of foreign conventions, styles and religions, it did

Dr. ERIC HIRSCH - Brunel University London; e-mail: Eric.Hirsch@brunel.ac.uk; ORCID: https://orcid.org/0000-0002-1690-9871. 
not lead to an attempt to understand them in their own terms and their relative qualities. If anything, the notion of an original human nature was revived in contrast to the existence of a variety of historical forms (cf. PAGDEN 1986).

Aesthetic historism, followed by general historism, practically originated in the second half of the eighteenth century, as a reaction against the European predominance of French classicism; the preromantic and Romantic currents created it and spread it all over Europe. The most vigorous impulse came from Germany ...

[F]rom the first works of Herder and Goethe. (AUERBACH 1949, 111)

Herder in contrast to previous thinking began from the idea of the original folk genius. Art and poetry was not based on the good taste and formal rules associated with an advanced civilisation. Rather, true or genuine aesthetic forms were the product of imagination and intuition. Ancient epic poetry, for instance, was not composed by individuals but emerged from many nameless sources such as the texts of Homer. In this conception, history was regarded less as a series of arbitrary facts and actions but as a slow movement of hidden forces, understood as the expression of the divine. Herder "admired the variety of historical forms as the realisation of the infinite variety of the divine spirit, manifesting itself through the genius of various peoples and periods" (AUERBACH 1949, 111).

This perspective on history led to the fervent research into individual historical and aesthetic forms. The idea was to try to understand them in their own terms - their development and transformation. It was a rejection of aesthetic classifications based on fixed and analytic criteria. As such, the movement associated with Herder and those associated with him led to the emergence of historism and that of modern historical sciences.

The task of the contemporary historian, art historian, art critic, as much as anthropologist, is to describe and interpret aesthetic and historical forms in their own terms. Each discipline will have their own ways of doing so, their own internal debates and whether art forms, for example, merit our attention or are seen as poorly executed in terms of prevailing aesthetic conventions (e.g. the controversies that surrounded Jackson Pollocks "drip paintings" at the time. Were these "art"?).

I have introduced the expansiveness of Western aesthetic and historical horizons in order to compare it with aesthetic and historical conventions from a very different context. The context is one found in the Papuan highlands of Papua New Guinea (PNG). Here live the Fuyuge people whose 
aesthetic and historical ideas are very different from that found in the West. At the same time, I will show that there is also a parallel between Fuyuge ideas and those found in the West.

Following my brief introduction of the Fuyuge people I discuss how I am using the notion of aesthetics in this Melanesian context. There are similarities with Western usage but there are also differences connected with distinctive ideas of cosmology and social relations. I examine Fuyuge ideas of aesthetics and how these are related to a cosmological figure. The cosmological figure is not only the source of Fuyuge aesthetic perceptions but also their ideas of history - the origin of things and how things change. I then turn to the Fuyuge ritual known as gab and discuss, among other matters, the aesthetic ideas that influence its form and content. In particular, I consider a new dance form introduced into Fuyuge ritual that led to debate about its appropriateness and especially its aesthetic qualities. By way of conclusion I compare Western aesthetic and historical understanding with Fuyuge aesthetic and historical understanding. Whereas the former is wide and relativistic the latter imagines all aesthetic and historical forms as deriving from their world.

\section{THE FUYUGE WORLD AND THE RITUAL OF $G A B^{1}$}

The Fuyuge people reside in the Wharton Ranges of Central Province, PNG. Their population is ca. 14000 (in 2000) and they live in five river valleys. The largest numbers of Fuyuge people live in the Udabe Valley which has a population of ca. 5000. This is the valley where I conducted my fieldwork in the mid-1980s and again in 1999. Within each valley the Fuyuge divide themselves into a number of territorial units with distinct Fuyuge dialects. I refer to these as "homes" $(\mathrm{em})$. I lived in the home named Visi where ca. 450 people resided.

Fuyuge social life is focused on the periodic organisation and performance of a ritual known as gab. It is staged in a specially built village, also known as gab. The ritual is organised to mark and celebrate the lifecycle transitions of the young, old and the dead. Dancers from other homes and valleys are invited to perform. Also invited are various categories of guests with whom exchange of different kinds are engaged. Large numbers of pigs are killed in the name of the young, old and dead marked in the ritual and this pork is then transacted with the dancers and guests.

\footnotetext{
${ }^{1}$ Portions of the material in the sections that follow are drawn from HIRSCH 2021.
} 
The Fuyuge world was created by a figure known as tidibe. Tidibe is said to have travelled from east to west forming the land and placing Fuyuge conventions and then disappearing when moving towards the seacoast. This cosmological figure is a creator force without material form but myths associated with this figure (also known as tidibe) have human-like form. The myths detail the origins of matters central to Fuyuge social life, such as the creation of female reproductive organs. I was told about tidibe when I conducted my fieldwork and people at the time wondered what became of the creator force. They suggested he travelled to the world of white people and that white people and the things they possessed originated from tidibe and thus, by implication, from Fuyuge lands. If anything, all that is of value in the world originated from tidibe and thus the Fuyuge.

Let me put what I was told into some historical context. In 1910 Robert Williamson made an "expedition" to what was then the Territory of Papua. ${ }^{2}$ Williamson was not a trained anthropologist (or ethnologist to use the term then current). He was a solicitor but had a desire "to see something of the savage life" as Haddon (Williamson 1912, xvii) refers to it in the introduction he wrote to Williamson's monograph. Both Haddon and Charles Seligmann assisted Williamson with his study which was just prior to Malinowski's Papuan fieldwork revolution in anthropology.

Five years previously in 1905 Father Paul Fastré established a mission station on Fuyuge lands in the Auga Valley at a place called Popole. He was a member of the Missionnaires du Sacré-Cœur (MSC) a mission of French origins. Williamson stayed at the mission during his three month stay and was assisted in his research by another of the missionaries, Father Clauser. Clauser was the first missionary to enter the neighbouring Udabe Valley in 1909. I mention all this in order provide something of the context in which Williamson gathered the material that was assembled in his book (WILLIAMSON 1912) and in particular what he wrote about the creator force, tidibe, at this point in time.

[T] here is a general belief among them in a mysterious individual named $[t]$ sidibe [tidibe in the Visi dialect], who may be a man, or may be a spirit (they appear to be vague as to this), who has immense power, and who once passed through their country in a direction from east to west. ... They believe that it was $[t]$ sidibe who taught them all their customs, including dancing and manufacture, and that he ultimately reached and remained in the land of the white man, where he is now living; and that the superior knowledge of the white man in manufacture, and

\footnotetext{
${ }^{2}$ It was no longer British New Guinea although he refers to it in those terms.
} 
especially in the making of clothes has been acquired from him. The idea of his ultimate association with the white man can hardly, however, be very ancient tradition. One of the Fathers was seriously asked by a native whether he had ever seen $[t]$ sidibe... As traces of his passage through their country they will show you extraordinarily shaped rocks and stones, such as fragments which have fallen from above into the valley, and rocks and stones which have lodged in strange positions. (WILLIAMSON 1912, 264-265)

At the time of my fieldwork the Fuyuge had a mission presence for over seventy five years in some valleys and the majority of the people were nominally Catholic. At the same time, views about tidibe were still strongly held. In fact, I was told a myth/tidibe shortly after I commenced fieldwork that told how the actions of the Fuyuge had brought the missionaries onto their lands. The missionaries and government arrived due to Fuyuge agency to the power of tidibe.

Prior to the movement of the creator force, though, there were people present on Fuyuge lands. They are now known as the "true people," but at that time they were like plants that "grew wild" (FASTRÉ n.d., 339). This included the original inhabitants of the land, the "fathers of the land" (bul $b a b)$, and the other people that were present, the people of the land (bul $u$ $a n)$. It is only when tidibe travelled from east to west that the land formed into its present state, that the amede (a type of leader) "were planted," the prototypes (vasa) of all significant things were placed, and tame and foreign spirits (sila) established across the landscape (FASTRÉ n.d., 336).

The creator force and all that was established with its movements is ultimately foreign or other. At the same time, the radical changes affected by the movement of tidibe means that transformation was an original and primary feature of Fuyuge patterns of action. The existence of tidibe and all that derives from it is constant- creating a cosmological pre-eminencewhile the world formed by tidibe may continually change.

It is amede that enable Fuyuge people to organise and perform gab ritual as the amede is understood to "look after" the people and allow them to attain a unity necessary for the ritual performance. In performing gab or any of their daily practices that flow into gab, such as tending to their gardens or pig rearing, the Fuyuge say they follow in the ways placed by tidibe. Fuyuge practices and conventions, then, have a particular aesthetic informed by the cosmological presence of tidibe. 


\section{AESTHETICS AND SKIN}

How am I using the notion of aesthetics in the Fuyuge context? It is different to the how the idea of aesthetics is understood by aesthetic historism. In the case of aesthetic historism it is a matter of critically understanding the specific "ways of seeing" of a society or culture in the present as well as historically. Every culture past and present has a culture-specific aesthetic and the task of the historian, anthropologist or art critic is to define and critically analyse the unique ways of seeing that results in the art produced by that culture (see BERGER 1990; PRICE 1989).

The way I am using aesthetics in the Fuyuge context is informed by Alfred Gell's critique of the study of "indigenous aesthetics" (Gell 1998) and by Marilyn Strathern's interpretation of the revelation of social relations in Melanesia (Strathern 1988). The target of Gell's $(1998,3)$ critique is the way the anthropology of art has conventionally been studied. He is doubtful that every culture "has a component of its ideational system which is comparable to our own aesthetics." The wish to view the art of other cultures through an aesthetics frame "tells us more about our own ideology and its quasi-religious veneration of art objects as aesthetic talismans, than it does about these other cultures." He suggests that a focus on "aesthetic principles" is misguided. Rather, what should be the focus of study is the "mobilisation of aesthetic principles ... in the course of social interaction" (Gell 1998, 4) In understanding any art the starting point for Gell is the social relations of persons $(1998,5)$.

Strathern's (1988) interests are not art but the form of Melanesian social relations. In focusing on social relations, though, she deploys the notion of aesthetics. The manner in which she uses the idea of aesthetics is comparable to Gell's idea of social interaction and the mobilisation of "aesthetic principles." Aesthetics as applied by Strathern concerns the way persons and the social relations of which they are composed appear to other persons in specific social contexts. Aesthetics in this way is intrinsically bound to the form taken by persons and social relations. Addressing the way Melanesians personify relations, making them appear in a distinctive form, Strathern (STRATHERN 1988, 181) states the following:

For a body or mind to be in a position of eliciting an effect from another, to evince power or capability, it must manifest itself in a particular concrete way, which becomes the eliciting trigger. This can only be done through the appropriate aesthetic. 
Strathern is suggesting that relations are "objectified" - materialisedin a limited number of ways (her argument considers this in connection to gender which I do not pursue here). "Only certain specific forms of interaction will be taken as evidence of the successful activation or maintenance of relationships" (STRATHERN 1988, 181). This can only be known and assessed when seen and what is perceived should appear correct, should assume the appropriate aesthetic form. If relations are visible in proper form - appear aesthetically correct-this is evidence of effectiveness and capability by those revealing such relations to others.

There is also a moral dimension to these acts of revelation and whether or not they appear in the aesthetically correct form: persons are judged by the way they activate relationships (STRATHERN 1988, 277). In all domestic and ritual events, persons are scrutinised and judge by others to assess whether their actions have followed ancestral convention and the assumed the aesthetically appropriate form (STRATHERN 1988, 278).

I will now show how the ideas of Gell and Strathern regarding the aesthetics of persons and social relations is applicable to the Fuyuge people and in particular the performances in their gab ritual, mentioned above.

Outside of the ritual context of $g a b$, the Fuyuge reside in small dispersed settlements. In order to organise and stage a gab ritual in a particular home, such as Visi where I lived, they must concentrate together. This is in order to first construct the ritual village. The coming together to a common purpose is facilitated by one or more amede in each home. The Fuyuge conceptualise this as becoming one mind (har fida) and one skin (hode fida) - becoming a unity.

The idea of skin is significant and bears directly on Gell and Strathern's remarks about aesthetics. People understand themselves as composed of skin they acquire through their maternal and paternal relations. In Visi, for instance, there are several "skin names"; these names are associated with the land as much with people. The skin names are the outcome of the past actions of men (and by implications women) in collective and personal undertakings (e.g. in gab ritual or in cultivating gardens). Skin is formed by theses past actions of men and women that are recreated in the present through analogous collective and personal endeavours. The notion can also be translated as relative or relation. Skin in this sense is a form of collective and personal identity and a person is composed of several "skins" depending on their relations.

In the context of gab diverse ways of thinking ( $\mathrm{mind} /$ har) and diverse social differences (skin/hode) are transcended through the agency of the 
amede. The notion of skin realised in the collective unity of gab ritual is analogous to the image of a tree branching: the single base holds numerous branches all visible on the skin/bark (hode) of the tree. The amede, as comparable to the base is what enables the plurality of men and women - all comparable to the branches - to come together and be amalgamated.

A person is composed of skin (relations) and skin is how the person is perceived (her or his external appearance). The same applies in a comparable manner to a collective of persons, such as what occurs when people concentrate together to perform gab. At the same time, though, the perceptible skin is where internal and hidden capacities and actions are revealed. The skin, then, is "read" to see what it discloses about the person or persons and those "things" persons are connected to such as other persons or garden foods and pigs (see O'HANLON 1989).

For example, a man whose yams do not grow properly or whose own skin becomes affected by disease will be seen as one who did not properly follow conventions, such as by committing adultery or having sexual relations with his wife before planting yams when this is forbidden. Yams of poor quality - with poor skin as this is expressed — or a man with diseased skin are both shameful states of affairs. The skin is where matters hidden and unseen are revealed. The poor quality of the skin renders this visible. Matters hidden, such as broken taboos, are revealed on the skin and the truth disclosed. Skin is the point of contact between what is hidden in the person (their mind, will or actions) and the world (see STRATHERn 1979).

The conventions that should be followed by the Fuyuge are said to derive from the creator force tidibe. How a garden is cultivated, pigs raised, marriages conducted, gab ritual organised and so on all come from this figure. This is why the Fuyuge will say that they follow in the ways of tidibe. The appearance of skin provides evidence of the appropriate or incorrect execution of convention originating from tidibe. It is this concern with skin that is foremost in the minds of the men and women that stage a gab ritual. It is why a unified appearance is important: it demonstrates that all minds are focused to a common purpose, to a common set of conventions and such unity is a sign of power to others.

The attainment of one skin is manifest in the form of the gab village. An oval shaped plaza forms the centre of the village and the entrances to houses adjoining the plaza face onto this space (see Figure 1).

The dispersed type of everyday settlement is transcended in gab. Diverse identities of skin are submerged. 


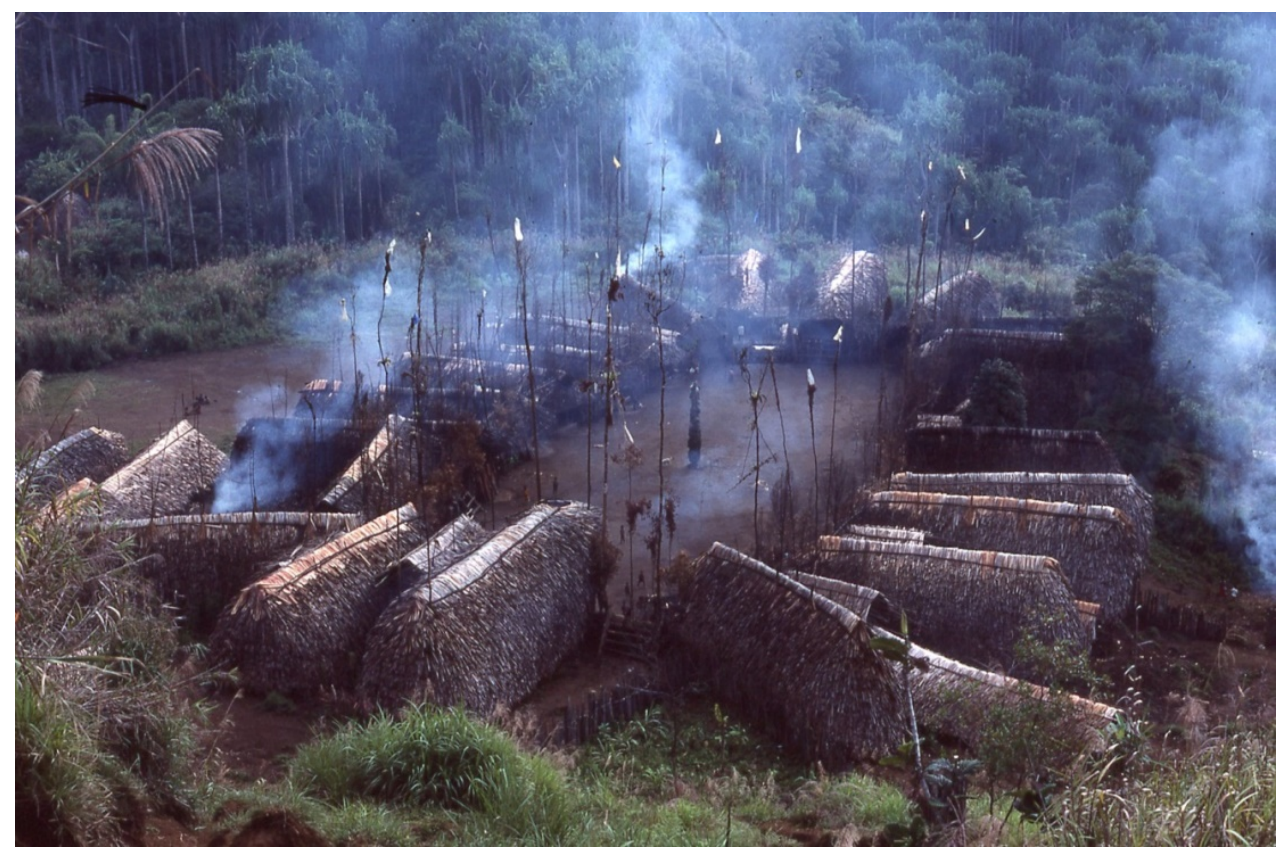

Figure 1: A gab village. Photo: E. Hirsch, 1984.

Throughout the conduct of the ritual there is an emphasis on maintaining and displaying one skin. This is the case for both the organisers (hosts) of the ritual and for the dancers invited to perform in the gab plaza. There is an overt competitive relation between hosts and dancers as each are concerned to demonstrate their power and effectiveness.

\section{ATTAINING ONE SKIN}

I will now briefly describe how this competitive relation transpires in time and how both hosts and dancers seek to sustain a unity of appearance one skin - in relation to the other. My description will leave out many details in order to focus attention on how an aesthetics of oneness is recurrently achieved.

Each host of the ritual organises the killing of pigs in the name of one or more young person, old person and dead person. In this he is supported with pigs from others, often those he has supported in the past. Each host has a kinship or marriage relation with those he is celebrating in the ritual. To- 
gether the hosts decide which home or homes they will challenge to dance. This may be a new challenge or the return of an older challenge presented to the hosts in the past. The dancers perform especially for the old people, known as the people with white hairs or mal. What is of interest here is the way the hosts invite the dancers and present their challenge.

The hosts make use of a single cordyline plant to invite each dancer. Outside of this ritual context cordyline is utilised to mark a boundary and in the past was given to a home or person as a challenge to assist in warfare or to kill an individual in revenge. The use of cordyline in $g a b$ by the hosts signals both a boundary between themselves and the dancers and highlights the war-like nature between them.

Individual dancers are invited by the hosts sponsoring each mal, although the men $^{3}$ who will later perform as dancers are not present. Many of the dancers are invited several times by individual hosts, especially if the man is well known and influential. The names of the dancers challenged to perform are announced one by one. This is done for each group of relations supporting every mal. The host proclaiming the names of the invited dancers is in each case given a cordyline by individual hosts sponsoring a mal and told the name and valuable the dancer should bring in exchange for pork distributed at the culmination of the ritual. He then holds each cordyline with an outstretched arm at a height just above his head. As the cordyline is brought to the ground he loudly states the name of the dancer and whether or not an exchange object is to be brought. As he progresses from one end of the plaza to the other a long single line of cordyline is assembled. The differences between all the mal and their relations are obscured through the process of challenging the dancers, creating an image of unity visible of the ground of the ritual plaza. This is an image of the hosts as one skin (see figures 2 and 3 ).

The hosts later take the cordylines to the home or homes of the invited dancers and repeat the above practice after which the cordylines are left with the dancers in a bundle. In the ritual village the hosts constructed an image of their unity within the plaza and then display this unity in the presence of the dancers through making their challenges visible. The dancers are now compelled to achieve an analogous united form when they come to perform in the $g a b$ village.

\footnotetext{
${ }^{3}$ Women also perform as dancers in the daytime dances but are not formally invited.
} 


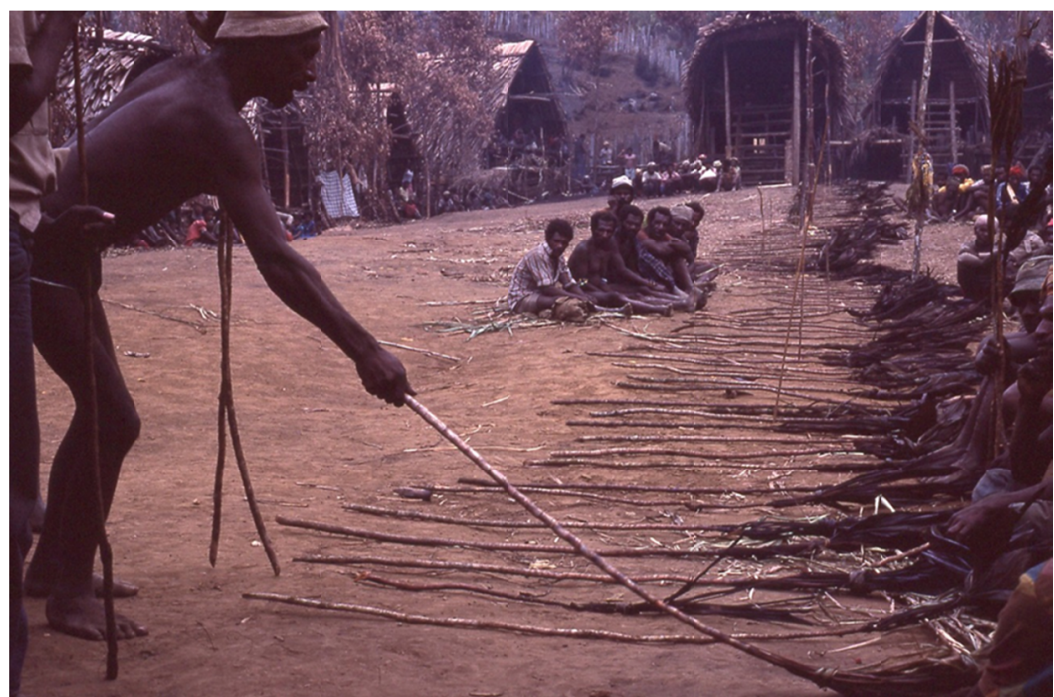

Figure 2: Presenting cordyline to the dancers. Photo: E. Hirsch, 1984.

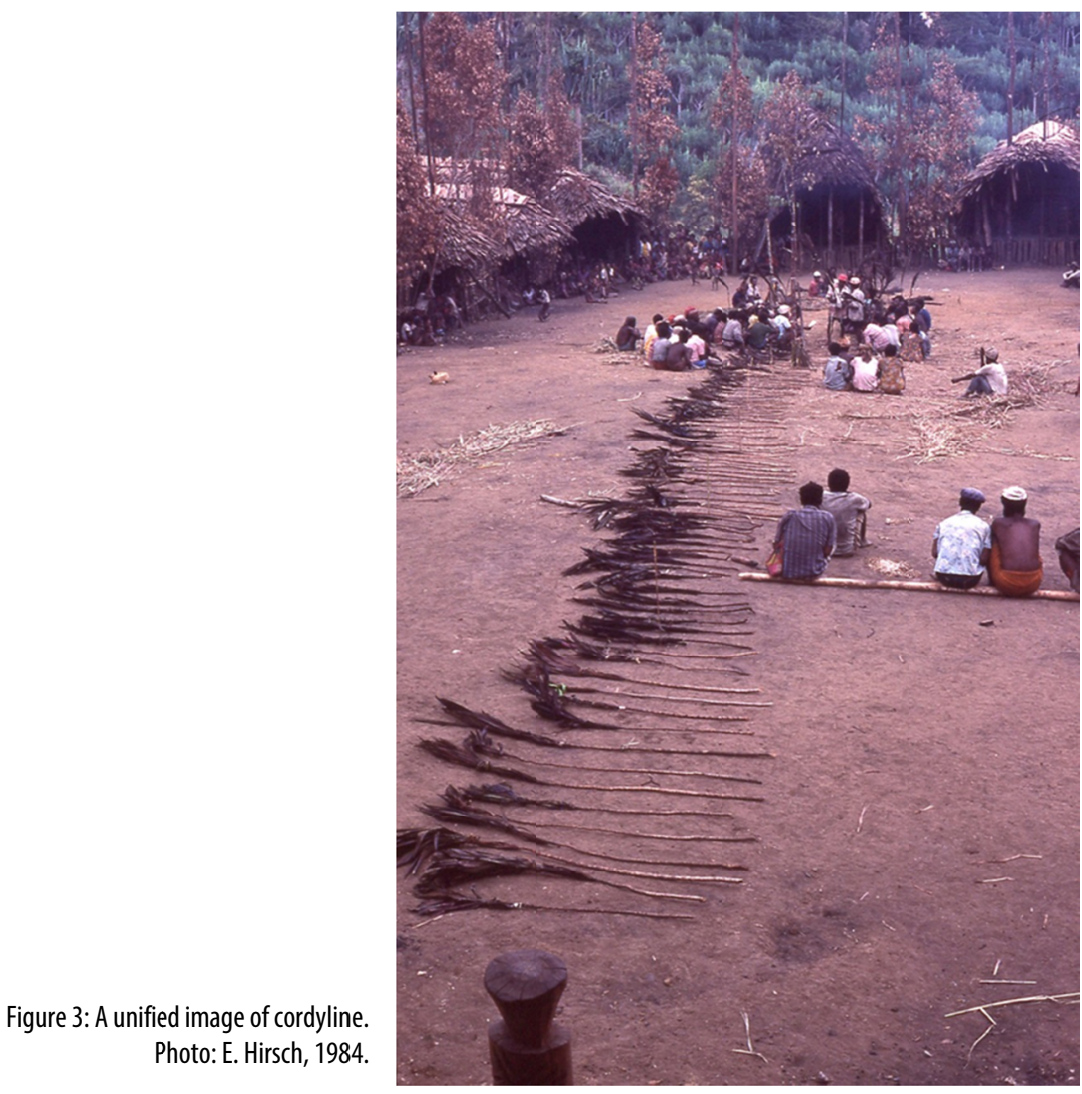


Just as the hosts need to supplement the number of pigs they possess in order to meet their exchange obligations and achieve an imposing display of sacrificed pigs, ${ }^{4}$ so the dancers seek to increase their numbers so that the scale of their dancing performances will be striking. Each side to this relation strives to outdo the other.

In order to magnify their numbers the invited dancers commence on a particular journey to the gab village itself. The invited dancers reside in hamlets and villages of the homes mentioned above. Kin and affines from the same home or neighbouring homes of the dancers are recruited to join them as they make their way to the gab. These other dancers are known as "the dancers' back." A number of small-scale rituals, comparable to elements of gab are staged as the dancers move geographically closer to the ritual village. In doing so the dancers are able to consolidate their numbers and unify their skin.

When the dancers eventually arrive in the vicinity of the gab they do not proceed to the ritual village itself. They reside some distance away in a structure hastily constructed by the hosts. The structure has no floor or walls and shelter is provided by the roof which slopes close to the ground. It is in this structure that the dancers prepare their adornments for the two daytime dances and the all night dance. The contrast in the living arrangements could not be greater between the dancers and the hosts, supporters with pigs and other guests who all reside inside the ritual village. The dancers are placed visibly as "other" (see BATESON 1958 [1936]), 176; SCHIEFFELIN 1976, 223; STRATHERN 1988, 14; cf. SAHLINS 2013). The hosts and dancers sustain their competitive difference, until the culmination of the gab.

\section{READING THE SKIN}

The dancers' bodies must be light and their skin unblemished. To accomplish both, the dancers undertake a regime of fasting before their performance. All relations with women are banned prior to the dancing performance, as is contact of water on the skin, both of which will negatively affect the skin's appearance. The skin can only be wiped with crushed croton leaves, the roots of special plants, plants with a strong perfume or brilliant colours, especially yellow, which colours the skin nicely or oily plants which make it shine.

\footnotetext{
${ }^{4}$ I do not describe any of the pig sacrifices in this article. There is a large-scale sacrifice that culminates the ritual.
} 
The Fuyuge perform three dances in gab: two daytime dances and one dance throughout the night until dawn. Each dance has a specific form but all are variants of one another. In their unique ways each is meant to clear the $g a b$ village of spirits of the dead so the old people, the mal, celebrated in the ritual can exist without shame. Instead of considering each dance in turn I will now consider a set of daytime dances performed by two homes in 1999. A new style of dance was introduced by one of the homes performing and this gave rise to a debate about the effectiveness of their performance. Much of the debate focused on their appearance - their skin — and what this revealed about their performance.

"Disco" was the new style of dance introduced into the second daytime dance. The second daytime dance is known as kere. "Disco" in this case refers to string-band music accompanied by a "stereotypical Polynesian dance, with swaying hips and undulating hand movements" (NILES 1998, 78). The dance is performed centrally by young women, while small groups of young men parade about them, some playing guitars with amplifiers. They perform songs that have melodies with lyrics in the local language or Tok Pisin.

Fuyuge dance forms have been continually transforming and disco was the most recent change in the late 1990s. Although dance forms have been continually changing these changes are understood to be caused by the continuity of Fuyuge cosmological pre-eminence deriving from tidibe. The Fuyuge acknowledge their dances and how they are performed in gab need to follow ancestral precedent. However, what is perceived at any moment to be ancestral precedent is open to differing interpretations.

In this respect, the disco dance form and other dance forms performed by the Fuyuge can all be seen as potentially analogous. This is because what is relevant is the appearance or "skin" of the dancers. Do the actual skins of the dancers look new and refreshed; are their adornments appropriate for the occasion; do the dancers look unified and powerful in their performance?

On the day of the daytime dances the men and women performing their kere dance in the style of disco went first. The dancers all wore short headdresses, many with kere (Electus Parrot) feathers. Around twenty women and twenty men occupied the plaza and danced disco in the style described above. They all sang string band songs and were accompanied by men playing amplified guitars (see figures 4 and 5). Their performance lasted no more than thirty minutes. The contrast with the conventional kere performance I knew from the past was conspicuous. The local assessments focused less on the style of dance - the arrangements of the men and women - or on the singing, but on the dancers' appearance. 


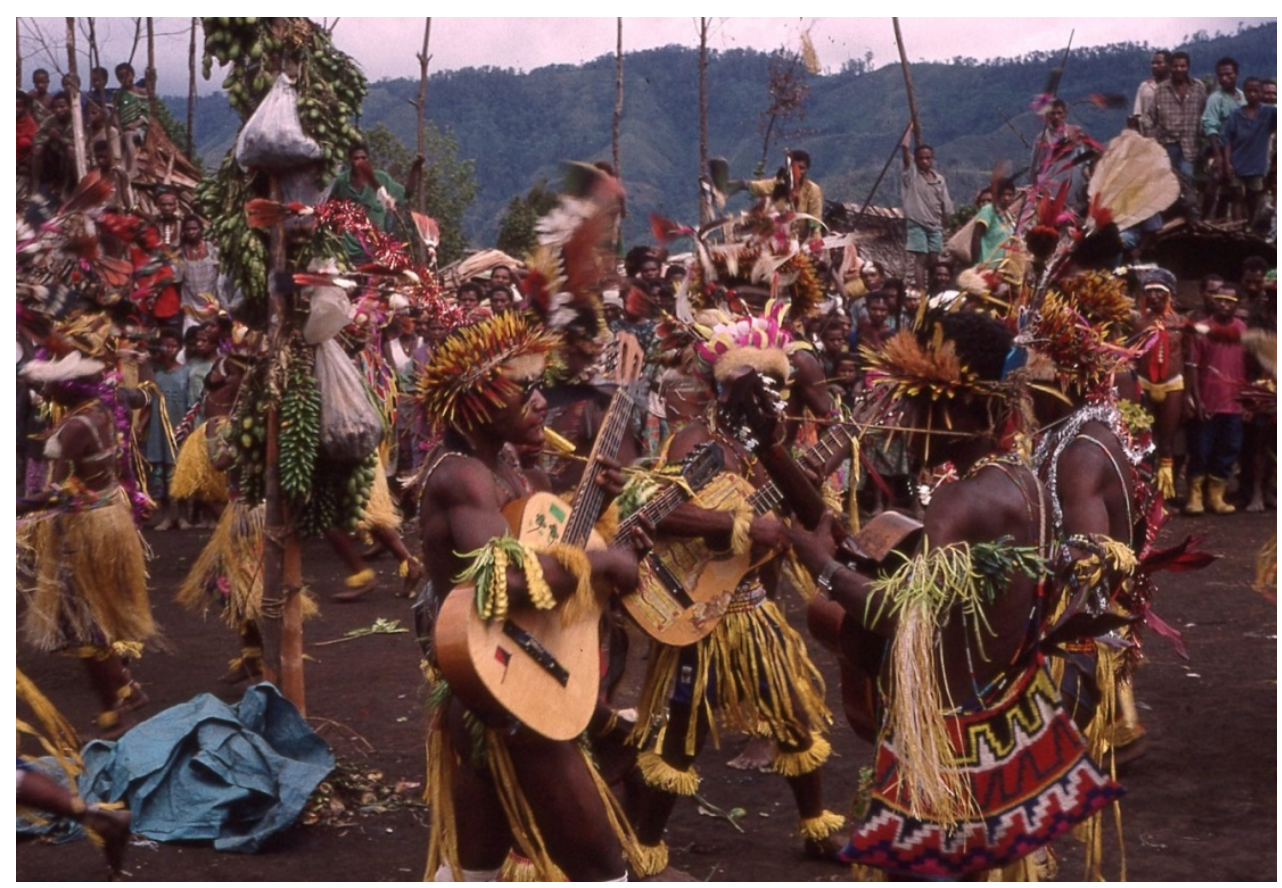

Figure 4: Disco kere — men playing guitars. Photo: E. Hirsch, 1999.

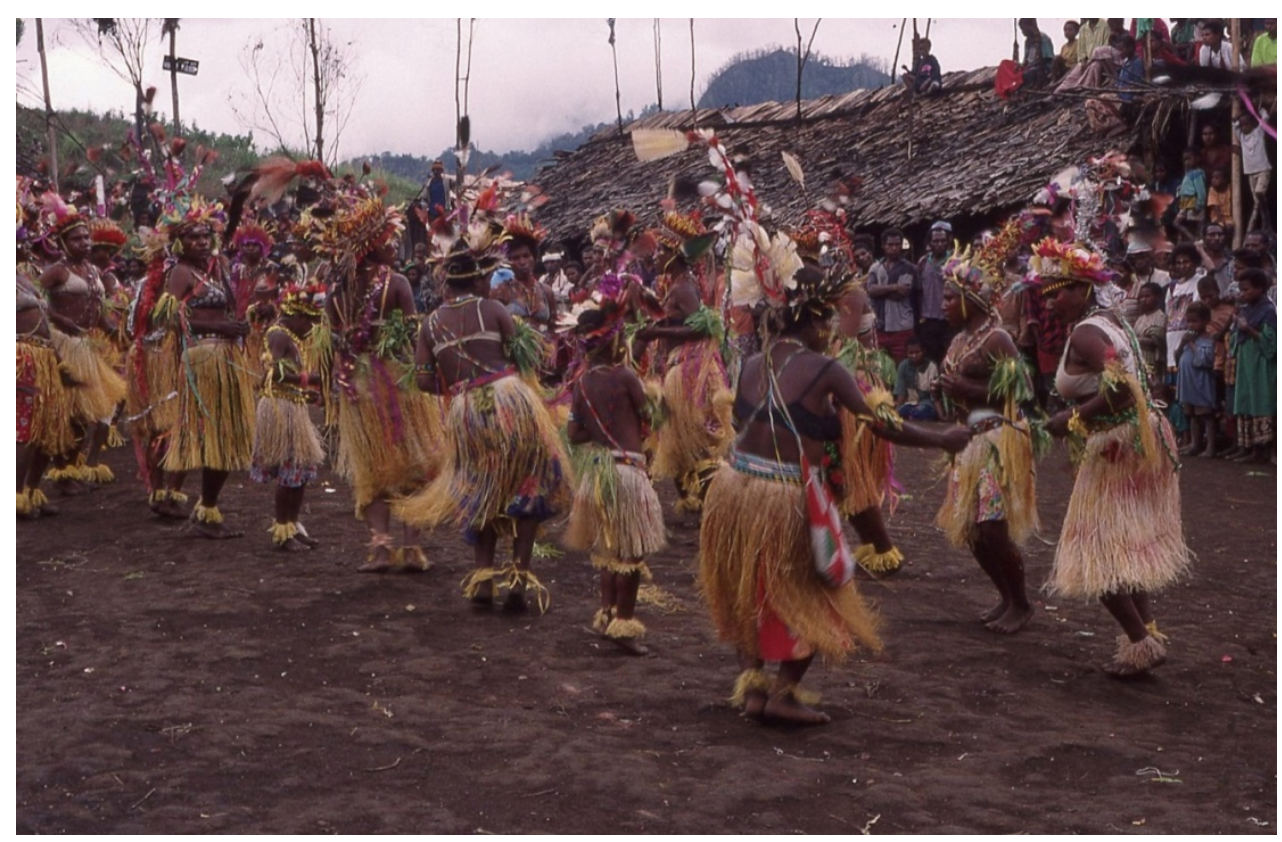

Figure 5: Disco kere — women dancing. Photo: E. Hirsch, 1999. 
One assessment indicated that the dancers' tops (i.e. their headdresses) were fine but from the face to the feet were not good. It was said their appearance would not chase the spirits of the dead away for the men and women mal. This was because their body adornments were not appropriate for the kind of headdress they had donned: some dancers were wearing shoes, hats, shorts, shirts and their bodies were not in a good state. Others echoed this view: the dancers had been invited to perform but they had not cleared the plaza of spirits; they had not properly assisted with removing the shame of the mal.

In fact, one of the mal spoke while the dancers were performing and called them to stop. He said: "It is not good when you play the guitar" (Git hadan ko). He told the dancers he had made gab for his brothers in the past. He thought that one day when his relations mark his mal it would be good. But he told them that they had come with poor decorations: "My spirits will not go and stay on the mountains" (Na sila ye kuntu me andam me), i.e. you did not take my shame away. What he meant by this is that the shame of white hairs is "washed away" by gab and specifically a ritual plaza clear of spirits of the dead. His view is that the dancers did not accomplish this with their adornments.

Two days later the other dancers performed their daytime dances. In particular, their kere dance was similar and recognisable to what I witnessed in other gab: they danced with drums, moving from one end of the plaza to the other (see figure 6). When the dancers entered the plaza and performed, people were silent - no praiseworthy comments occurred as might occur on such occasions. Afterward I was told people did not speak because they did not want to further shame the other dancers. This difference in the way the two performances were assessed influenced, in turn, the speeches later made at the ritual.

One of the hosts speaking held a headdress decorated with kere feathers in one hand and a ten kina ${ }^{5}$ note in the other. He then spoke to the audience:

This is my power (kagava) [showing the headdress]; this is the white man's power [showing the ten kina note]. Mine is gone. I am not going to bring it back: Papua New Guinea and Australia, our power [money]. This is your flower. Get this thing and when anybody wants to cook his pumpkin [i.e. make a gab] and invites you, you get this and go. And if he asks you to go and play guitar you get this and lead your people and go. This one is at the back of me now [i.e. headdress].

\footnotetext{
${ }^{5}$ Kina is the Papua New Guinea currency. As of November 20201 kina is equivalent to .21 British Pound.
} 


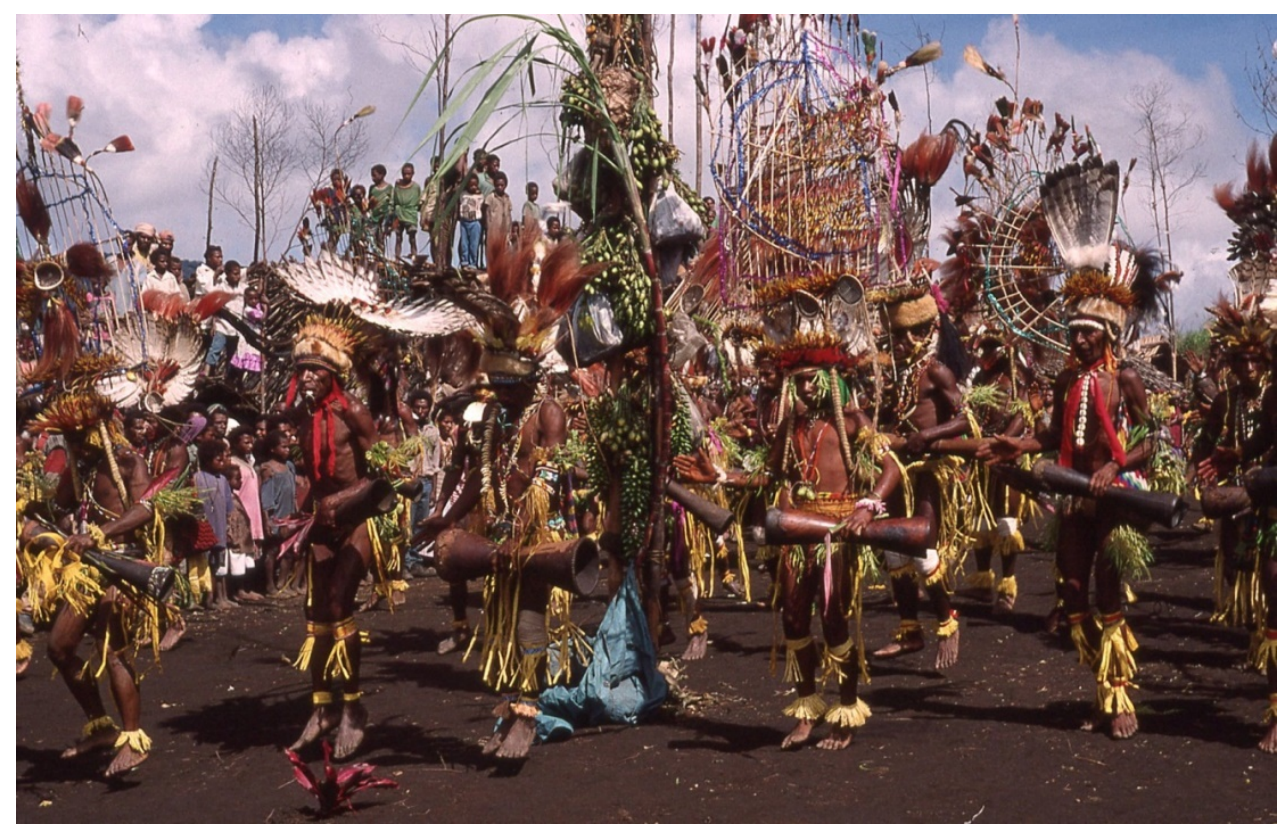

Figure 6: Kere dancers. Photo: E. Hirsch, 1999.

Shortly after this speech another host rose and spoke to the audience. Like the first speaker he held a kere headdress and ten kina note in his hands:

This is white's thing, this is our, black's thing. I am not going to throw one and hold onto the other. The two will go up together [his two index fingers pointing together] ... Sometime in the future the white man will tell me, show me your traditional ways of dancing. If I leave custom and the white man asks me to show him in the future, what will I show him? ${ }^{6}$ [The white man says]: "You dance your custom" and what will I do? I might look for ways. "Law" [money] and custom must go together.

Both speakers were commenting on the dancing performances from previous days and trying to influence how the audience might have experienced and evaluated each. The first speaker was instrumental in inviting the dancers who performed disco and his speech was as much about supporting their performance as it was endorsing his own standing. The second speaker was contesting the first speaker's interpretation of the

\footnotetext{
${ }^{6} \mathrm{He}$ was referring to white visitors that infrequently fly to the mission station and seek out customary practices, such as traditional adornments and dancing.
} 
dancing performances, what they revealed about the Fuyuge peoples' current situation more generally. He was also involved in inviting the second dancers and had their performance as well as his status to secure.

The first host was suggesting that money is the true power now and by implication disco, not that of conventional kere dancing. The second host was arguing that kere dancing cannot be supplanted by money (disco). By joining his index fingers together he conjured an image of co-existence. The debate between the two was about whether new ways or practices were appropriate and whether older practices should be supplanted by the new. Should disco become recognised as ancestral convention - in place of kere performed with drums - or should both be recognised as conventions following the ways established by tidibe? Which one manifests the appropriate aesthetic? This is always a contested issue for Fuyuge people who have diverse perceptions and expectations about what conventions should transpire now and in the future.

\section{CONCLUSION}

In the case of both groups of dancers the central concern was the appearance of their skin, whether their performance revealed capacities deriving from tidibe. The assessments and debates about the dancing performances especially that of the disco performers were chiefly about whether they had elicited the appropriate aesthetic.

As everything in the world ultimately derives from tidibe a new dance style such as disco is no different. Its performance must be seen as following "aesthetic principles" that are in accordance with what tidibe created in the ancestral past. This can only be perceived and known when it is revealed on the skin, that is, when the dancers perform and their performance is assessed to ascertain whether an appropriate aesthetic has been revealed.

Aesthetic historism gave rise to an idea of art and aesthetics whereby it is possible to view each culture as having its own culture-specific aesthetic that is worthy of understanding and analysis (Cf. Gell 1998, 1). Aesthetics from this standpoint, then, is universal like the orthodox Western view of history. This "universal history" operates according to the notion that everything that has happened belongs to a single and determinate realm of unchanging actuality. ("What is done is done. You can't change the past"). This is meant to be the case whether considering the history of Britain or Papua New 
Guinea. However, for the Fuyuge people what Westerners refer to as history - its universality - is for them understood to derive from tidibe.

As everything in the world ultimately derives from tidibe, then, for Fuyuge people there is not an aesthetics that is separate from tidibe. For the Fuyuge tidibe informs how all people and things are perceived and what is revealed by reading the skin as it is manifest in each context and instance. Aesthetic historism views aesthetics as a universal - every people has its own aesthetics. The aesthetics of tidibe is also universal, in a symmetrically inverted manner to that of aesthetic historim: everything in the world and how it is perceived - its aesthetic - derives from one source, from Fuyuge lands formed by tidibe.

\section{BIBLIOGRAPHY}

Auerbach, Erich. 1949. "Vico and aesthetic historism." The Journal of Aesthetics and Art Criticism 8, no. 2: 110-118.

BAteSON, Gregory. 1958 [1936]. Naven: a survey of the problems suggested by a composite picture of the culture of a New Guinea tribe drawn from three points of view. Stanford: Stanford University Press.

Berger, John. 1990. Ways of seeing. London: BBC and Penguin Books.

FASTRÉ, Paul, n.d. "Manners and customs of the Fuyuges" [unpublished manuscript translated by M. Flower, O.C.D. and E.Chariot, O.C.D., de Boismenu College, Boroko - translation of Mouers et coutumes Foujougheses, 1937-1939].

Gell, Alfred. 1998. Art and agency: an anthropological theory. Oxford: Oxford University Press.

Hirsch, Eric. 2021. Ancestral presence: cosmology and historical experience in the Papuan highlands. London: Routledge.

NiLes, Don. 1998. "Papua New Guinea: an overview." In International encyclopedia of dance, edited by Selma Jeanne Cohen, 76-78. New York: Oxford University Press.

O'HANLON, Michael. 1989. Reading the skin: adornment, display and society among the Wahgi. London: British Museum.

Pagden, Anthony. 1986. The fall of natural man: the American Indian and the origins of comparative ethnology. Cambridge: Cambridge University Press.

Price, Sally. 1989. Primitive art in civilised places. Chicago: University of Chicago Press.

SAhlins, Marshall. 2013. "Difference." Oceania 83, no. 3: 281-294.

SCHIEFfELIn, Edward L. 1976. The sorrow of the lonely and the burning of the dancers. New York, St. Martins Press.

Strathern, Marilyn. 1988. The gender of the gift: Problems with women and problems with society in Melanesia. Berkeley, CA: University of California Press.

Strathern, Marilyn. 1979. "The self in self-decoration." Oceania 49, no. 4: 241-257.

Williamson, Robert W. 1912. The Mafulu mountain people of British New Guinea. London: Macmillan. 


\section{AESTHETIC HISTORISM AND THE AESTHETICS OF TIDIBE: RITUAL, PERFORMANCE AND CONTESTED PERCEPTIONS OF "SKIN" IN THE PAPUAN HIGHLANDS}

$\mathrm{Sum}$ m a ry

The article focuses on a series of dances performed in Fuyuge (Papua New Guinea) ritual, one of which provokes debate about its ancestral appropriateness. I use these examples to examine the distinctiveness of Fuyuge aesthetics and historical understanding as compared with Western aesthetics and historical understanding. Whereas the latter is geographically wide and relativistic the former imagines all aesthetics and historical forms as deriving from the Fuyuge world.

Keywords: aesthetics; historism; cosmology; dance; Fuyuge, Papua New Guinea.

\section{HISTORYZM ESTETYCZNY I ESTETYKA TIDIBE: RYTUAŁ, PERFORMANCE I KONTROLOWANE POSTRZEGANIE „SKÓRY” W PAPUASKICH GÓRACH}

Streszczenie

Artykuł skupia się na serii tańców wykonywanych w rytuale Fuyuge (Papua Nowa Gwinea), z których jeden prowokuje dyskusję na temat jego rodowej stosowności. Korzystam z tych przykładów, aby zbadać odrębność estetyki Fuyuge i rozumienia historii w porównaniu z estetyką zachodnią i zachodnim rozumieniem historycznym. Podczas gdy te drugie są geograficznie obszerne i relatywistyczne, te pierwsze wyobrażają sobie całą estetykę i formy historyczne jako wywodzące się ze świata Fuyuge.

Przełożyt Stanisław Sarek

Słowa kluczowe: estetyka; historyzm; kosmologia; taniec; Fuyuge, Papua Nowa Gwinea. 